\title{
Comparative Study on Dynamic Analysis of Irregular Building with Shear Walls
}

\author{
Le Yee Mon \\ Civil Engineering Department, \\ Mandalay Technological University, \\ Mandalay, Myanmar
}

\begin{abstract}
South East Asia including Myanmar is situated in secondary seismic belt. Therefore, it is necessary to pay special attention of the effect of earthquake in designing the high-rise building. Shear walls are very common in high rise reinforced concrete building. In this study, comparative analysis of high-rise reinforced concrete irregular building with shear walls are present. The frame type of proposed building is used the special RC moment resisting frame. It belongs to seismic zone 4 . This is why, seismic forces are essentially considered in the analysis of this building and shear walls are also provided to resist seismic forces. Structural members are designed according to ACI Code 318-02. The structure is analysed by using ETABS v 9.7.1 software. Load consideration is based on UBC-97. All necessary load combinations are considered in shear walls analysis and frame analysis. In addition wind load, seismic load is considered as external lateral load in the dynamic analysis. In dynamic analysis; Response Spectrum method is used. In this project, study of 14 storey building is presented with some investigation which is analyzed by changing various location of shear wall for determining parameters like storey drift, storey shear and storey moment .
\end{abstract}

Key words: Shear wall; Response Spectrum method; ETABS software; dynamic comparisons

\section{INTRODUCTION}

Myanmar is a developing country and the population of Myanmar is increasing more and more. Mandalay, the second largest city of Myanmar, lies in a serious earthquake more and more. Therefore, in constructing the residential buildings, it should be designed to resist not only gravity loading such as dead load and live load but also horizontal loading such as wind load and seismic load. The proposed building being located in Mandalay should be designed to withstand not only gravity forces but also lateral forces, as Mandalay is situated in flat terrain and severe earthquake zone. Structural wall system is much stiffer than a frame system and its performance during an earthquake is better than the performance of the frame system. In this study, shear walls are provided for reinforced concrete building to obtain the required stiffness and strength to withstand lateral load like wind and seismic. There are three types of shear wall. They are planar shear wall, coupled shear wall and core shear wall. To obtain the required stiffness and strength to withstand lateral load in high- rise building, shear walls are normally included some frames of the building. They are continuous down to the base to which they are rigidly attached to form vertical cantilever. Therefore, the magnitudes of moment and horizontal shear are found to be maximized at the base and they become less as they become high. The positions of shear walls within a building are dictated by functional requirements. They may or may not suit structural planning. Building sites, architectural interests may lead, on the other hand, to positions of walls that one undesirable from a structural point of view. Hence, structural designers will often be in the position desirable locations for shear wall in order to optimize lateral force resistance. Shear wall are efficient, both in terms of construction cost and effectiveness in minimizing earthquake damage in structural and non- structural. Shear walls can reduce total deflection and the beams connected to the shear wall need to have the larger member size.

\section{PREPARATION 2.1 Site Location and Structural System}

The type of building is fourteen storey Y- shaped reinforced concrete residential building with shear walls. The location of proposed building is in Mandalay (seismic zone 4) and only the wind velocity of $80 \mathrm{mph}$ is considered. The maximum dimension is $128 \mathrm{ft}$ in Global- $\mathrm{X}$ direction and $136 \mathrm{ft}$ in Global-Y direction. The overall height of the structure is 159 $\mathrm{ft}$. The type of occupancy is residential (four unit for one storey). Model (1) is the special moment resisting frame (SMRF) structural system and other three models are composed of shear walls and SMRF (dual type) structural system. In this structure, response spectrum dynamic analysis is used. Plan and $3 \mathrm{D}$ view of proposed building are described in Figure 1, 2 and 3. 


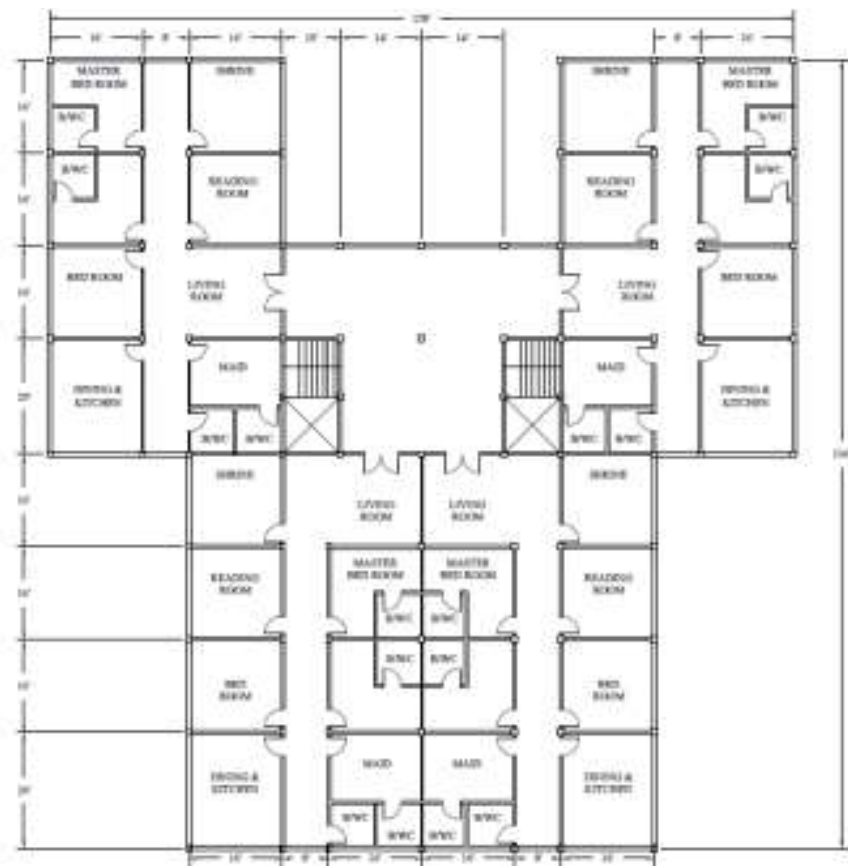

Figure 1: Plan of the proposed building

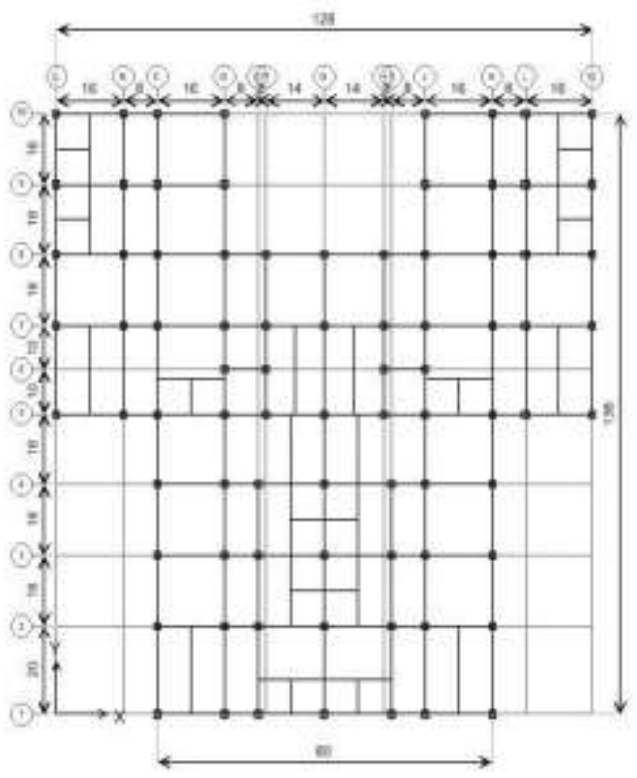

Figure 2: Plan of the proposed building

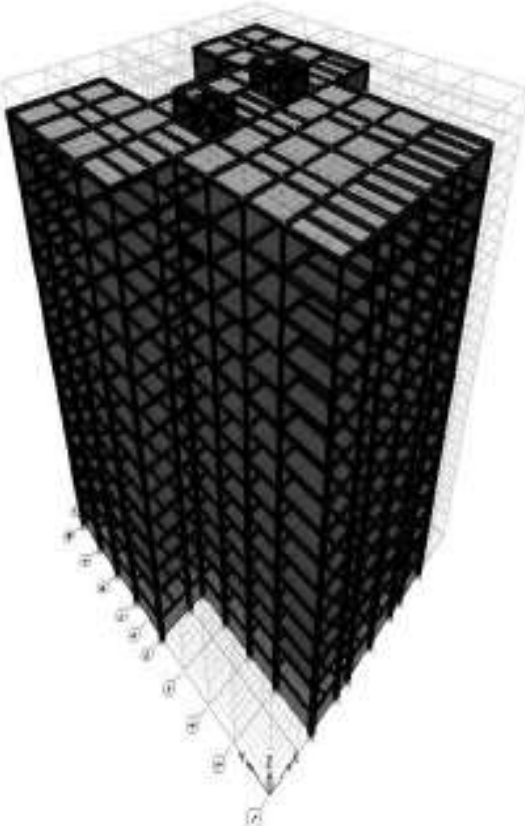

Figure 3: Three dimensional of the proposed building

\subsection{Material Properties}

The strength of a structure depends on the strength of the materials from which it is made for this purpose; material strength is specified in standardized ways as a step to proceed the design of a structure.

Analysis property data

\begin{tabular}{|l|l|}
\hline $\begin{array}{l}\text { Weight per unit volume of } \\
\text { concrete }\end{array}$ & $150 \mathrm{lb} / \mathrm{ft}^{3}$ \\
\hline Modulus of elasticity, $\mathrm{E}_{\mathrm{C}}$ & $3.122 \times 10^{6} \mathrm{lb} / \mathrm{in}^{2}$ \\
\hline Poisson's ratio, $\mu$ & 0.2 \\
\hline Coefficient of thermal expansion & $5.5 \times 10^{-6} \mathrm{in} /$ in $\mathrm{per}^{\circ} \mathrm{F}$ \\
\hline
\end{tabular}

Design property data

\begin{tabular}{|l|l|}
\hline Bending reinforcement yield stress $\left(\mathrm{f}_{\mathrm{v}}\right)$ & $50,000 \mathrm{lb} / \mathrm{in}^{2}$ \\
\hline Shear reinforcement yield stress $\left(\mathrm{f}_{\mathrm{y}}\right)$ & $50,000 \mathrm{lb} / \mathrm{in}^{2}$ \\
\hline Concrete cylinder strength $\left(\mathrm{f}_{\mathrm{c}}\right)$ & $3,000 \mathrm{lb} / \mathrm{in}^{2}$ \\
\hline
\end{tabular}

\subsection{Loading considerations}

The gravity loads considered in this design are dead load and live load. The lateral loads of wind load and earthquake load are calculated according to UBC-97.

(1) Gravity load

Dead load is defined as the results from the structure and all other permanently attached materials. They have constant magnitude and fixed location throughout the lifetime of the 
structure. The characteristic feature of dead load is that they are permanent. Live loads are produced by the use and occupancy of the building or other structure and do not include dead load, construction load and environmental loads. Live loads may be either fully or partially in place or not present at all and may also change a position.

Dead Load data are as follow:

\begin{tabular}{|l|l|}
\hline Unit weight of concrete & $150 \mathrm{lb} / \mathrm{ft}^{3}$ \\
\hline $4 \frac{1}{2} 2^{\text {" thick wall weight }}$ & $50 \mathrm{lb} / \mathrm{ft}^{2}$ \\
\hline 9" thick wall weight & $100 \mathrm{lb} / \mathrm{ft}^{2}$ \\
\hline Superimposed dead load & $20 \mathrm{psf}$ \\
\hline Weight of elevator & 3 tons \\
\hline
\end{tabular}

Live Load data are as follow:

\begin{tabular}{|l|l|}
\hline Live load on residential area & $40 \mathrm{lb} / \mathrm{ft}^{2}$ \\
\hline Live load on roof & $30 \mathrm{lb} / \mathrm{ft}^{2}$ \\
\hline Live load on stair case & $100 \mathrm{lb} / \mathrm{ft}^{2}$ \\
\hline Weight of water & $249.6 \mathrm{psf}$ \\
\hline
\end{tabular}

(2)Wind Load

Every building or structure and every portion shall be designed and constructed to resist the wind effects. Wind shall be assumed to come from any horizontal direction.

Wind load data are as follow:

\begin{tabular}{|l|l|}
\hline Exposure type & Type B \\
\hline Basic wind velocity & $80 \mathrm{mph}$ \\
\hline Important factor & 1 \\
\hline Windward coefficient & 0.8 \\
\hline Leeward coefficient & 0.5 \\
\hline Method used & Normal force method \\
\hline
\end{tabular}

(3)Earthquake Load

Earthquake load data are as follow;

\begin{tabular}{|l|l|}
\hline Location & Mandalay \\
\hline Seismic zone & Zone 4 \\
\hline Zone factor, $Z$ & 0.4 \\
\hline Soil type & $\mathrm{S}_{\mathrm{D}}$ \\
\hline Importance factor, $\mathrm{I}$ & 1.0 \\
\hline Response modification factor, $\mathrm{R}$ & 8.5 \\
\hline Seismic coefficient, $\mathrm{C}_{\mathrm{a}}$ & $0.44 \mathrm{~N}_{\mathrm{a}}$ \\
\hline Seismic coefficient, $\mathrm{C}_{\mathrm{v}}$ & $0.64 \mathrm{~N}_{\mathrm{v}}$ \\
\hline Near source factor, $\mathrm{N}_{\mathrm{a}}$ & 1.0 \\
\hline Near source factor, $\mathrm{N}_{\mathrm{v}}$ & 1.0 \\
\hline Analysis types & Dynamic Analysis \\
\hline
\end{tabular}

\section{(4). Load Combinations}

Design codes applied are ACI 318-02 and UBC-97.There are 30 numbers of load combinations which are used in the structural analysis.

\begin{tabular}{|l|l|}
\hline NO & COMBINATIONS \\
\hline COMB 1 & 1.4 D.L \\
\hline COMB 2 & 1.2 D.L + 1.6L.L \\
\hline COMB 3 & 1.2 D.L + L.L + 1.6 WXP \\
\hline COMB 4 & 1.2 D.L + L.L -1.6 WXP \\
\hline COMB 5 & 1.2 D.L + L.L + 1.6 WXN \\
\hline COMB 6 & 1.2 D.L + L.L - 1.6 WXN \\
\hline COMB 7 & 1.2 D.L + L.L + 1.6 WYP \\
\hline COMB 8 & 1.2 D.L + L.L - 1.6 WYP \\
\hline COMB 9 & 1.2 D.L + L.L + 1.6 WYN \\
\hline COMB 10 & 1.2 D.L + L.L - 1.6 WYN \\
\hline COMB 11 & 1.2 D.L + 0.8 WXP \\
\hline COMB 12 & 1.2 D.L -0.8 WXP \\
\hline COMB 13 & 1.2 D.L + 0.8 WXN \\
\hline COMB 14 & 1.2 D.L - 0.8 WXN \\
\hline COMB 15 & 1.2 D.L + 0.8 WYP \\
\hline COMB 16 & 1.2 D.L - 0.8 WYP \\
\hline COMB 17 & 1.2 D.L + 0.8 WYN \\
\hline COMB 18 & 1.2 D.L - 0.8 WYN \\
\hline COMB 19 & 0.9 D.L + 1.6 WXP \\
\hline COMB 20 & 0.9 D.L - 1.6 WXP \\
\hline COMB 21 & 0.9 D.L + 1.6 WXN \\
\hline COMB 22 & 0.9 D.L -1.6 WXN \\
\hline COMB 23 & 0.9 D.L + 1.6 WYP \\
\hline COMB 24 & 0.9 D.L - 1.6 WYP \\
\hline COMB 25 & 0.9 D.L + 1.6 WYN \\
\hline COMB 26 & 0.9 D.L - 1.6 WYN \\
\hline COMB 27 & 1.4 D.L + L.L + SPECX \\
\hline COMB 28 & 1.4 D.L + L.L + SPECY \\
\hline COMB 29 & 0.9 D.L + SPECX \\
\hline COMB 30 & 0.9 D.L + SPECY \\
\hline
\end{tabular}

\section{METHODS OF DYNAMIC ANALYSIS}

Dynamic analysis method

UBC-97 presents two types of dynamic analysis method for seismic response of a structure. They are;

(1) Response spectrum analysis; and

(2) Time-history analysis.

Of these two methods, response spectrum analysis is more convenient than time history analysis.

Response spectrum analysis

A response spectrum is the graphic representation of maximum response i.e. displacements, velocity and acceleration of a 
damped single-degree-of-freedom system to a specified ground motion, plotted against the frequency or modal periods.

The response spectrum has the following characteristics.

(i) The model must be constructed as an elastic system i.e. the model must be moved and swayed by the excitation but there was no yielding.

(ii) A single value of damping is used for each model response.

In the response spectrum analysis, the distribution of seismic lateral force on the building is based on the deformed shapes of natural modes of vibration, which are determined from the distribution of mass and stiffness of the structure. From the response spectrum, a specified spectra value can be read. This value is used to calculate the theoretical maximum seismic force acting on a structure .

$$
\mathrm{V}=\frac{\mathrm{WS}_{\mathrm{a}}}{\mathrm{g}}
$$

where,

$\mathrm{V}=$ theoretical maximum seismic force

$\mathrm{S}_{\mathrm{a}}=$ spectral acceleration read from spectrum

$\mathrm{g}=$ acceleration due to gravity $\left(9.81 \mathrm{~m} / \mathrm{sec}^{2}\right)$

$\mathrm{W}=$ effective weight

This analysis produces the complete time history response of joint displacements and member forces eliminating the time variable from the solution. For design purpose, the response spectrum should be representative of all seismic properties of specific site. It not, it may be constructed according to the spectral shape presented by UBC-97 by using site dependent seismic response coefficients.

Response spectrum analysis provides a rational and practical approximate method based on fundamental principles of dynamics and random vibration. Response spectrum analysis procedure involves the evaluation of the maximum value of structure response such as displacements and member forces for each mode of vibration using a spectrum of earthquake records. In response spectrum analysis model modes are first calculated, and then approximate total structural response is obtained by combining the model response in a statistical manner. Modal combination methods are Complete Quadratic Combination (CQC), Square Root of the Sum of the Square (SRSS), Absolute Sum Square (ABS), and General Modal Combination (GMC). In Complete Quadratic Combination (CQC), modal combination technique takes into account the statistical coupling between closely spaced modes caused by modal damping. Increasing the modal damping increases the coupling between closely spaced modes. Square Root of the Sum of the Square (SRSS) technique does not take into account any coupling of modes as do the CQC and GMC methods. In this study, CQC is used for modal combination. It is important to note that most building codes require the mode shapes to generate at least $90 \%$ of the participating mass of the structure in each of the three lateral directions.

\section{Design Criteria for Dynamic Analysis}

The procedure and limitations for the design of structures by UBC-97 are determined considering zoning, site characteristics, occupancy, configuration, structural system and height. For large or complex structures, static method of seismic analysis is often deemed to be not accurate enough and many authorities demand dynamic analysis for certain type and size of structure. The dynamic lateral-force procedures are always acceptable for design when a structure has any of the conditions listed below.

(1) Regular structure more than $240 \mathrm{ft}$ in height and located in seismic zone 2, 3 and 4 .

(2) In seismic zone 2, 3 and 4, a structure with stiffness, weight, or geometric vertical irregularity and have more than five stories or 65 feet in height must be designed with dynamic analysis.

(3) Structure in seismic zone 3 and 4 having more than five stories or $65 \mathrm{ft}$ with mixed vertical structural system.

(4) In zone 2, 3 and 4 all structure having a period of greater than 0.7 second and located on soil profile type $S_{\mathrm{F}}[97 \mathrm{UBC}]$.

\section{Design Spectrum for Proposed Building}

Design spectrum is a graph of time with respect to the peak ground acceleration. Design spectrum for proposed building is shown in Figure.4. The control periods $T_{s}$ and $T_{o}$ can be calculated by the formula;

$$
\begin{aligned}
\mathrm{C}_{\mathrm{a}} & =0.44, \mathrm{C}_{\mathrm{v}}=0.64 \\
\mathrm{C}_{\mathrm{t}} & =0.03, \mathrm{H}=159 \mathrm{ft} \\
\mathrm{T}_{\mathrm{s}} & =\frac{\mathrm{Cv}}{2.5 \mathrm{Ca}}=0.582, \mathrm{~T}_{\mathrm{o}}=0.2 \mathrm{~T}_{\mathrm{s}}=0.116, \\
\mathrm{~T} & =\mathrm{C}_{\mathrm{t}} \mathrm{H}^{3 / 4}=1.34 \mathrm{sec}
\end{aligned}
$$

When $\mathrm{T}=0$, spectral acceleration $=\mathrm{C}_{\mathrm{a}}=0.44$

When $\quad \mathrm{T}=\mathrm{T}_{\mathrm{o}}$ to $\mathrm{T}_{\mathrm{s}}$, spectral acceleration $=2.5 \mathrm{C}_{\mathrm{a}}=1.1$

When $\mathrm{T}>\mathrm{T}_{\mathrm{s}}$, spectral acceleration $=\mathrm{C}_{\mathrm{v}} / \mathrm{T}$

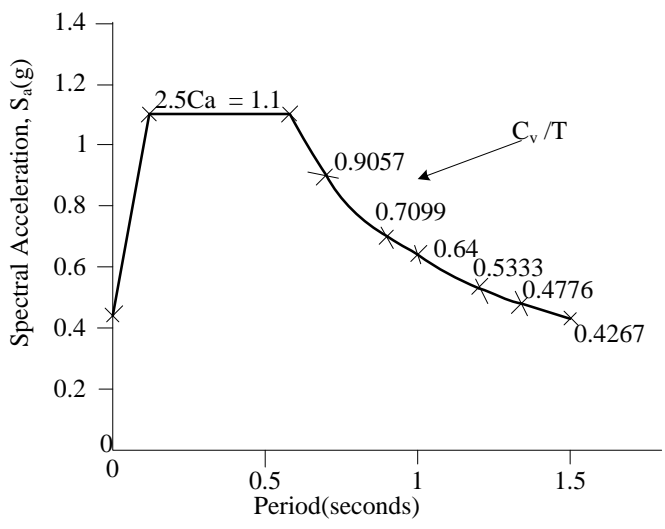

Figure 4: Design Spectrum for Proposed Building (5\% damping) 


\section{STRUCTURAL MODELLING}

Four buildings of 14 stories irregular in plan are modeled as of fixed base building and analyzed with soft computing tool ETABS V 9.7.1. Dynamic responses of building are studied. Four irregular model consists of symmetry in $\mathrm{X}$ direction of plan as well as elevation and $\mathrm{Y}$ direction plan asymmetry but elevation symmetric. In this study, the models are constructed with different contributions shear wall are used. The cross sectional dimensions of beams, columns and slabs are the same in the four models. And also, the material properties, loading and other data for wind and seismic forces are the same in the four models. The four cases of the building separately for comparison of storey drift, storey shear and storey moment are Case no. 1 .Without shear wall (Model 1), Case no. 2. When core shear wall placed at stair case \& lift of building (Model 2), Case no.3. When core shear wall placed at stair case \& lift of the building and planar shear walls placed at outer edge symmetrically parallel to $\mathrm{X}$ direction and planar shear walls placed at re-entrant corners (model 3).Case no. 4. When core shear wall placed at stair case \& lift of building and planar shear walls placed at outer corner symmetrically $\mathrm{X}$ and $\mathrm{Y}$ direction (Model 4).Model 1,2,3,4 are shown in figure 5,6,7,8 respectively. The structural member sizes used in proposed both models are shown in the followings.

\begin{tabular}{|c|c|}
\hline Column sizes & $\begin{array}{l}12 " \times 12 ", 14 " \times 14 ", 16 " \times 16 ", \\
18 " \times 18 ", 19 " \times 19 ", 20 " \times 20 ", \\
22 " \times 22 ", 24 " \times 24 " \text { and } 26 " \times 26 "\end{array}$ \\
\hline Beam sizes & $\begin{array}{l}-10 " \times 12 ", 10 " \times 14 ", \\
10 " \times 16 ", 10 " \times 18 ", 12 " \times 16 ", \\
12 " \times 18 ", 14 " \times 18 ", 14 " \times 20 "\end{array}$ \\
\hline Floor slab thickness & $4.5^{\prime \prime}$ \\
\hline Landing slab thickness & $4.5^{\prime \prime}$ \\
\hline Stair slab thickness & $4.5^{\prime \prime}$ \\
\hline $\begin{array}{l}\text { Shear wall Thickness } \\
\text {-GF to } 2^{\text {nd }} \text { floor }\end{array}$ & $14 "$ \\
\hline$-3^{\text {st }}$ floor to $7^{\text {th }}$ floor & $12 "$ \\
\hline$-8^{\text {th }}$ floor to Roof floor & $10 "$ \\
\hline
\end{tabular}
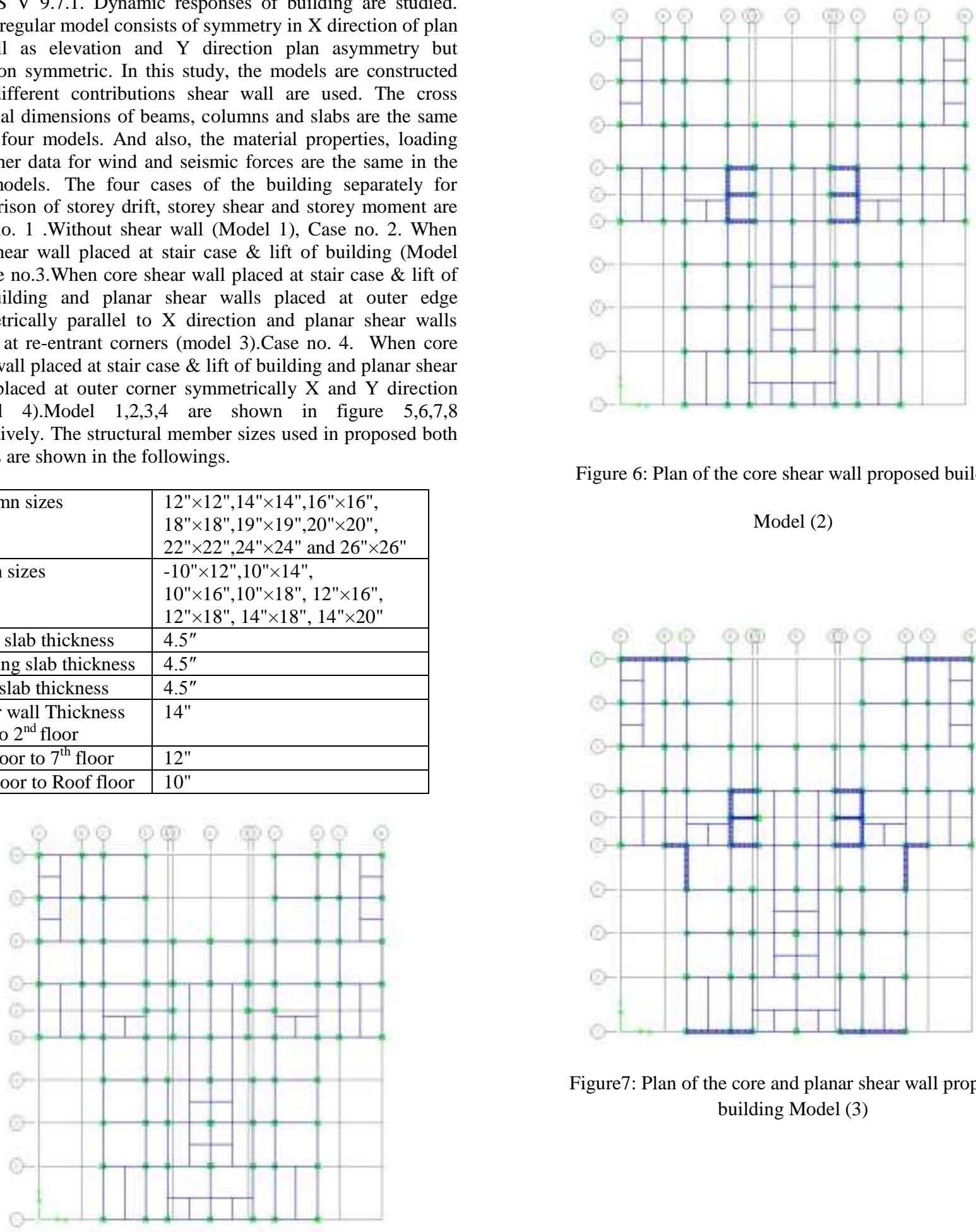

Figure 6: Plan of the core shear wall proposed building

Model (2)

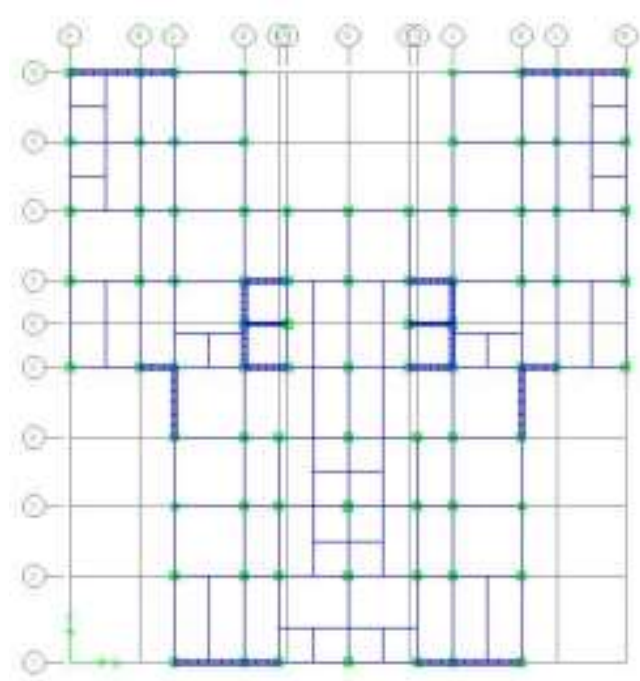

Figure7: Plan of the core and planar shear wall proposed building Model (3)

Figure 5: Plan of the non shear wall proposed building Model (1) 


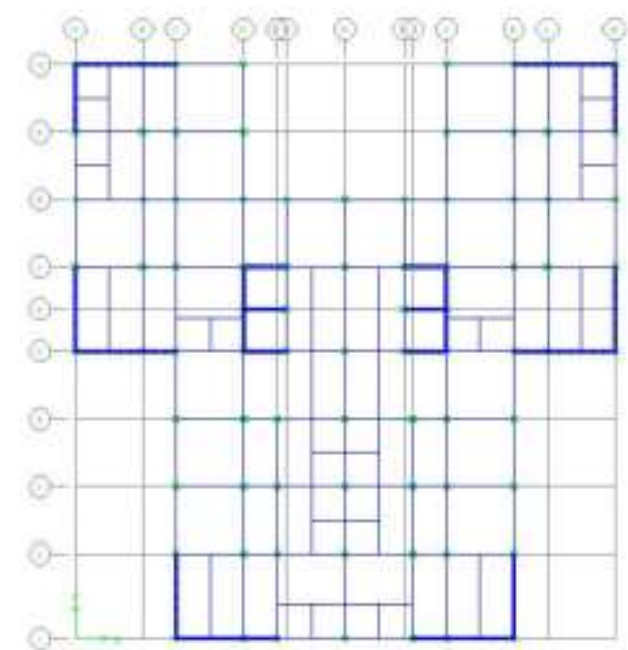

Figure8: Plan of the core and planar shear wall proposed building

Model (4)

\section{ANALYSIS RESULT}

The analysis of all the frame models that includes different location of shear walls has been done by using software ETABS and the results are shown below. The parameters which are to be studied are storey drift, storey shear and storey moment. Results obtained from the analysis are recorded for the four cases of the building separately for comparison of storey drift, storey shear and storey moment.

Table 1. Storey Drifts in X Direction Comparison

\begin{tabular}{|c|l|l|l|l|}
\hline \multirow{2}{*}{ Story } & \multicolumn{4}{|c|}{ Storey Drifts in X Direction } \\
\cline { 2 - 5 } & Model 1 & Model 2 & Model 3 & Model4 \\
\hline Roof & 0.001058 & 0.001426 & 0.00125 & 0.001044 \\
\hline 13 & 0.001287 & 0.001505 & 0.001263 & 0.001056 \\
\hline 12 & 0.001398 & 0.001547 & 0.001268 & 0.001061 \\
\hline 11 & 0.001464 & 0.001592 & 0.001268 & 0.00106 \\
\hline 10 & 0.001631 & 0.001648 & 0.001259 & 0.001052 \\
\hline 9 & 0.00167 & 0.001656 & 0.001236 & 0.001031 \\
\hline 8 & 0.001741 & 0.00167 & 0.001196 & 0.000995 \\
\hline 7 & 0.001704 & 0.001619 & 0.001134 & 0.000937 \\
\hline 6 & 0.001678 & 0.001574 & 0.001059 & 0.000874 \\
\hline 5 & 0.00163 & 0.00149 & 0.000969 & 0.000798 \\
\hline 4 & 0.001627 & 0.001393 & 0.00086 & 0.000707 \\
\hline 3 & 0.001608 & 0.001236 & 0.000731 & 0.000601 \\
\hline 2 & 0.001704 & 0.001049 & 0.000573 & 0.00047 \\
\hline 1 & 0.001815 & 0.00081 & 0.000389 & 0.000323 \\
\hline GF & 0.00099 & 0.000403 & 0.000183 & 0.000172 \\
\hline
\end{tabular}

Table 2. Storey Drifts in Y Direction Comparison

\begin{tabular}{|c|l|l|l|l|}
\hline \multirow{2}{*}{ Story } & \multicolumn{4}{|c|}{ Storey Drifts in Y Direction } \\
\cline { 2 - 5 } & Model 1 & Model 2 & Model 3 & Model4 \\
\hline Roof & 0.001031 & 0.001138 & 0.001095 & 0.000953 \\
\hline 13 & 0.00123 & 0.001162 & 0.001115 & 0.000953 \\
\hline 12 & 0.001291 & 0.001173 & 0.001126 & 0.000957 \\
\hline 11 & 0.001409 & 0.001179 & 0.001131 & 0.000959 \\
\hline 10 & 0.001503 & 0.00118 & 0.001129 & 0.000951 \\
\hline 9 & 0.001563 & 0.00117 & 0.001118 & 0.000934 \\
\hline 8 & 0.001603 & 0.001144 & 0.001092 & 0.000904 \\
\hline 7 & 0.001604 & 0.001091 & 0.001039 & 0.000853 \\
\hline 6 & 0.001552 & 0.001028 & 0.00098 & 0.000798 \\
\hline 5 & 0.001525 & 0.000957 & 0.000908 & 0.000732 \\
\hline 4 & 0.001539 & 0.000867 & 0.000818 & 0.000651 \\
\hline 3 & 0.001637 & 0.000759 & 0.00071 & 0.000555 \\
\hline 2 & 0.00163 & 0.00062 & 0.000571 & 0.000438 \\
\hline 1 & 0.001812 & 0.000485 & 0.000425 & 0.000313 \\
\hline GF & 0.001087 & 0.000264 & 0.000224 & 0.000162 \\
\hline
\end{tabular}

Table 3. Storey Shears in X Direction Comparison

\begin{tabular}{|c|l|l|l|l|}
\hline \multirow{2}{*}{ Story } & \multicolumn{4}{|c|}{ Storey Shears in X Direction(Kips) } \\
\cline { 2 - 5 } & Model 1 & Model2 & Model 3 & Model 4 \\
\hline RF & 163.53 & 232.45 & 314.89 & 364.95 \\
\hline 13 & 311.39 & 410.46 & 584.13 & 710.87 \\
\hline 12 & 426 & 535.47 & 784.11 & 987.85 \\
\hline 11 & 515.73 & 629.87 & 937.65 & 1213.35 \\
\hline 10 & 587.66 & 708.43 & 1064.01 & 1402.75 \\
\hline 9 & 646.08 & 777.11 & 1174.93 & 1566.39 \\
\hline 8 & 696.5 & 840.61 & 1278.06 & 1712.68 \\
\hline 7 & 742.93 & 904.28 & 1379.79 & 1850.84 \\
\hline 6 & 789.9 & 970.95 & 1482.84 & 1984.76 \\
\hline 5 & 840.75 & 1038.79 & 1584.37 & 2110.78 \\
\hline 4 & 895.93 & 1106.5 & 1682.55 & 2226.86 \\
\hline 3 & 952.75 & 1170.84 & 1771.4 & 2326.95 \\
\hline 2 & 1006.88 & 1226.97 & 1844.68 & 2406.89 \\
\hline 1 & 1051.43 & 1268.84 & 1897.57 & 2464.62 \\
\hline GF & 1058.81 & 1276.39 & 1908.4 & 2478.39 \\
\hline
\end{tabular}


International Journal of Science and Engineering Applications

Volume 3 Issue 2, 2014, ISSN-2319-7560 (Online)

Table 4. Storey Shears in Y Direction Comparison

\begin{tabular}{|c|r|r|r|r|}
\hline \multirow{2}{*}{ Story } & \multicolumn{3}{|c|}{ Storey Shears in Y Direction (Kips) } \\
\cline { 2 - 5 } & Model 1 & Model2 & Model 3 & Model 4 \\
\hline RF & 165.3 & 277.08 & 310.9 & 361.97 \\
\hline 13 & 318.63 & 508.59 & 581.5 & 703.23 \\
\hline 12 & 437.74 & 681.69 & 785.29 & 973.71 \\
\hline 11 & 530.79 & 813.53 & 942.92 & 1191.83 \\
\hline 10 & 606.63 & 920.43 & 1071.5 & 1374.08 \\
\hline 9 & 668.08 & 1012.94 & 1183.04 & 1531.69 \\
\hline 8 & 719.71 & 1098.43 & 1286.45 & 1673.36 \\
\hline 7 & 767.51 & 1182.71 & 1387.84 & 1808.12 \\
\hline 6 & 816.04 & 1269.38 & 1490.15 & 1939.88 \\
\hline 5 & 867.58 & 1357.2 & 1591.93 & 2065.12 \\
\hline 4 & 923.65 & 1445.01 & 1692.18 & 2182.01 \\
\hline 3 & 982.64 & 1527.7 & 1784.59 & 2284.4 \\
\hline 2 & 1039.55 & 1599.37 & 1863.37 & 2367.72 \\
\hline 1 & 1086.53 & 1655.09 & 1924.75 & 2429.47 \\
\hline GF & 1094.39 & 1666.12 & 1939.65 & 2445.55 \\
\hline
\end{tabular}

Table 6. Storey Moment in Y Direction Comparison

\begin{tabular}{|c|r|c|c|r|}
\hline \multirow{2}{*}{ Story } & \multicolumn{4}{|c|}{ Storey Moment in Y Direction(Kips-in) } \\
\cline { 2 - 5 } & \multicolumn{1}{|c|}{ Model 1 } & Model2 & Model 3 & \multicolumn{1}{c|}{ Model 4 } \\
\hline RF & 20405.83 & 29714.49 & 40077.82 & 46263.28 \\
\hline 13 & 57562.01 & 78677.48 & 109873.9 & 131284.5 \\
\hline 12 & 108005 & 141926.8 & 203014.8 & 249044.5 \\
\hline 11 & 168475.7 & 215027.4 & 313111.5 & 392730.7 \\
\hline 10 & 236619.2 & 295505.5 & 436049.4 & 557307.8 \\
\hline 9 & 310480.9 & 381979.1 & 569398.4 & 739134 \\
\hline 8 & 388736.8 & 473735.2 & 711928.8 & 935746.1 \\
\hline 7 & 470612.8 & 570606.7 & 863275.8 & 1145788 \\
\hline 6 & 555851.4 & 672882.2 & 1023590 & 1368550 \\
\hline 5 & 644724.9 & 781046.2 & 1193143 & 1603430 \\
\hline 4 & 737801.6 & 895524.1 & 1372134 & 1849826 \\
\hline 3 & 835722.8 & 1016530 & 1560415 & 2106790 \\
\hline 2 & 938951 & 1143965 & 1757373 & 2373040 \\
\hline 1 & 1069698 & 1304438 & 2003398 & 2702395 \\
\hline GF & 1182752 & 1442550 & 2213823 & 2982045 \\
\hline
\end{tabular}

Table 5. Storey Moment in X Direction Comparison

\begin{tabular}{|c|r|r|r|r|}
\hline \multirow{2}{*}{ Story } & \multicolumn{4}{|c|}{ Storey Moment in X Direction(Kips-in) } \\
\cline { 2 - 5 } & Model 1 & \multicolumn{1}{|c|}{ Model2 } & \multicolumn{1}{c|}{ Model 3 } & \multicolumn{1}{c|}{ Model 4 } \\
\hline RF & 20613.14 & 35305.51 & 39515.12 & 45848.44 \\
\hline 13 & 58704.17 & 96109.32 & 109002.8 & 129958.5 \\
\hline 12 & 110754.1 & 177193.8 & 202299 & 245999.8 \\
\hline 11 & 173213.1 & 272903.2 & 313117.9 & 387005.7 \\
\hline 10 & 243695.6 & 379458.5 & 437211.9 & 547914.8 \\
\hline 9 & 320260.9 & 494553.6 & 571902.6 & 725179.6 \\
\hline 8 & 401436.4 & 616997 & 715795.1 & 916493 \\
\hline 7 & 486339.6 & 746400.5 & 868430.6 & 1120660 \\
\hline 6 & 574692.6 & 882943 & 1029879 & 1337132 \\
\hline 5 & 666725.8 & 1027055 & 1200391 & 1565475 \\
\hline 4 & 762959.4 & 1179178 & 1380251 & 1805264 \\
\hline 3 & 864064.2 & 1339512 & 1569467 & 2055739 \\
\hline 2 & 970591.9 & 1507856 & 1767604 & 2315785 \\
\hline 1 & 1105548 & 1719271 & 2015651 & 2638217 \\
\hline GF & 1222281 & 1900833 & 2228254 & 2912511 \\
\hline
\end{tabular}

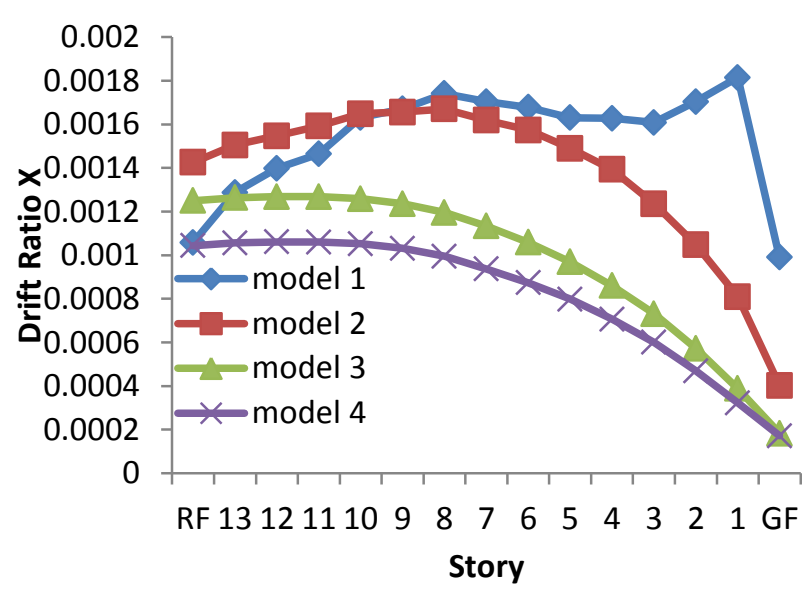

Figure.9 Comparison of Story Drift in X-direction 


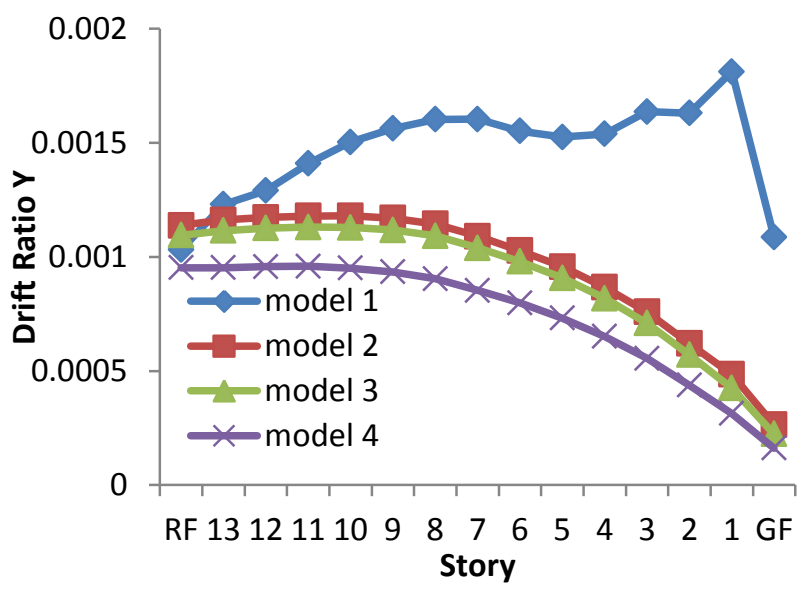

Figure 10. Comparison of Story Drift in Y-direction

The comparative study of storey drift values in $\mathrm{X}$ and $\mathrm{Y}$ directions for three models are represented in Table 1, Table 2 and Figure 9, Figure 10. The storey drift values of the non-shear wall structure (Model 1) is 2.24 times higher than that of Model (2) , 4.66 times greater than those of Model (3) and 5.62 times greater than those of Model (4) in X-direction at story 1. The storey drift values of the non-shear wall structure (Model 1) is 3.73 times higher than that of Model (2), 4.26 times greater than those of Model (3) and 5.79 times greater than those of Model (4) in Y-direction at story 1 . Thus, the story drift in structure with core shear wall and planar shear wall (Model 4) has the smallest value in both directions for all models.

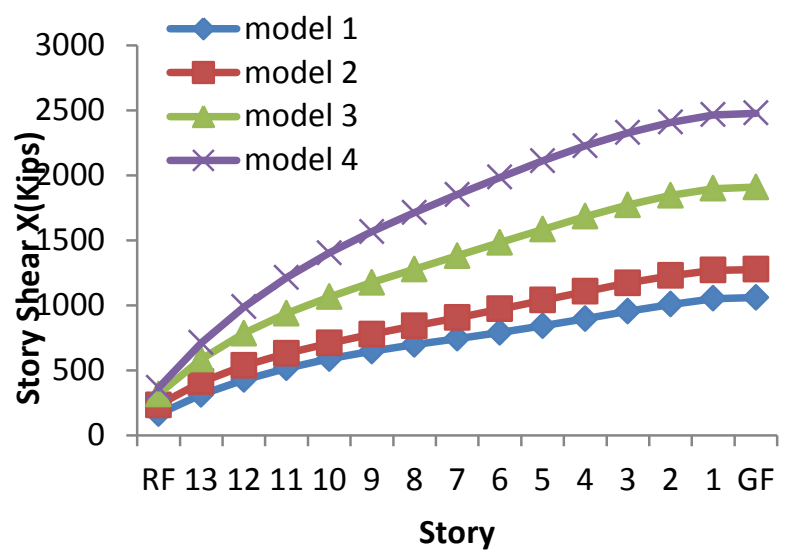

Figure 11.Comparison of Story Shear in X-direction

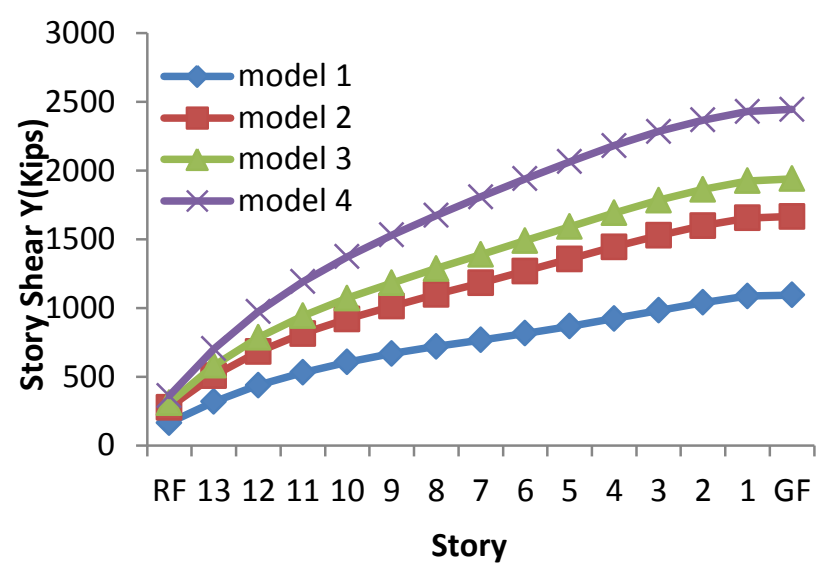

Figure 12.Comparison of Story Shear in Y-direction

The comparative study of storey shear values in $\mathrm{X}$ and $\mathrm{Y}$ directions for three models are represented in Table 3, Table 4 and Figure 11, Figure 12. In comparison of story shear in both directions, shears are increased steadily and maximum story shears are found in ground floor. The weight of the structure with core shear wall and planar shear wall (Model 4) is greater than other three structures. The storey shear values of the nonshear structure (Model 1) is 1.21times less than that of Model (2), 1.80 times less than those of Model (3) and 2.34 times less than those of Model (4) in X -direction at ground floor. Structure without shear wall has the least story shear and structure with core shear wall and planar shear wall (Model 4) has the greatest story shear.

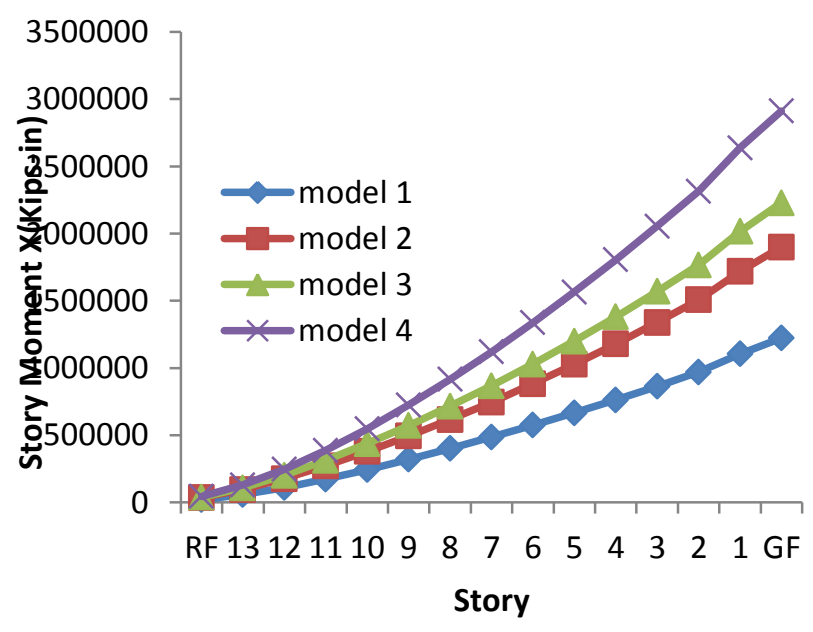

Figure 13.Comparison of Story Moment in X-direction 


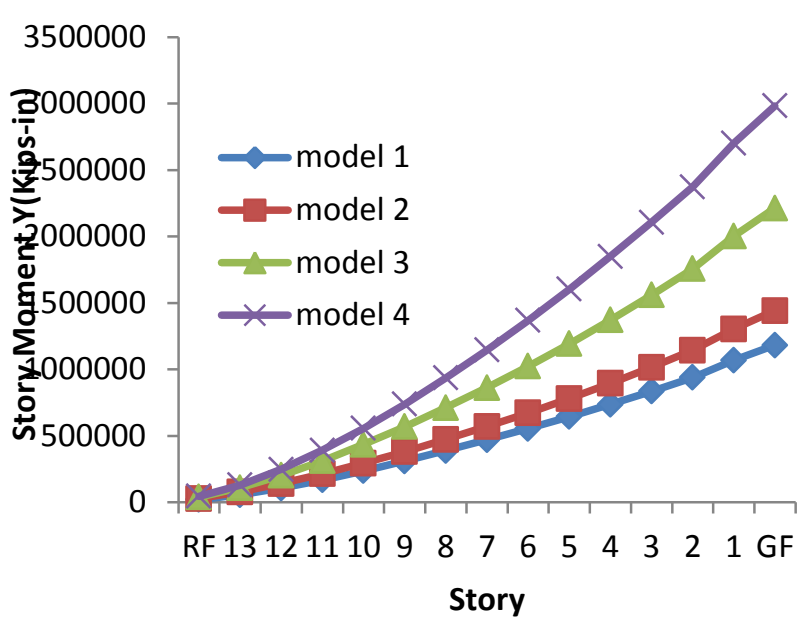

Figure 14.Comparison of Story Moment in Y-direction

The comparative study of storey moment values in $\mathrm{X}$ and $\mathrm{Y}$ directions for three models are represented in Table 5, Table 6 and Figure 13, Figure 14. In comparison of story moment in both directions, moments are increased steadily and maximum story moments are found in ground floor. The story moment is depending on the seismic load. So, the story moment is the largest at base. The storey moment values of the non-shear wall structure (Model 1) is 1.56 times slightly less than that of core shear wall structure and 1.82 times less than those of that of Model (3), and 2.38 times less than those of Model (4) in Xdirection at ground floor. The storey moment values of the nonshear wall structure (Model 1) is 1.22 times slightly less than that of core shear wall structure and 1.87 times less than those of that of Model (3), and 2.52 times less than those of Model (4) in Y-direction at ground floor. Structure without shear wall has the least story moment and structure with core shear wall and planar shear wall (Model 4) has the greatest story moment.

\section{DISCUSSIONS AND CONCLUSIONS}

In this study, the analysis of fourteen storeyed Y-shaped highrise reinforced concrete building in seismic zone 4 is done by ETABS v 9.7.1 software using response spectrum analysis. After analyzing the model, the stability checking is made for each model. Storey drift and torsional irregularity effect are checked by using UBC - 97 Formula. And then it is checked for overturning and resistance to sliding. The structural elements are designed by using American Concrete Institute (ACI 318-02). Shear wall are provided for lateral stability of reinforced concrete structure. The proposed building and the location of shear walls may or may not suit the functional requirements or the architectural interest. . From the results of storey drift, storey drifts in $\mathrm{X}$ and Y-direction of model 4 are less than that of other three models. From the results of storey shears, storey shears in $\mathrm{X}$ and $\mathrm{Y}$-direction of model 4 are greater than that of model 1, 2, 3. Storey shears are greatest at the base and gradually decrease from base to top storey for four models. Storey moments are slightly increased from top to bottom storey for all models. From comparative study, especially, model 4 is more reduced the story drift in both directions and it is suitable from structural point of view.

From the dynamic analysis of 14 storey RC building with plan irregularity we have got the following conclusions.

(1)The influence of shear wall location on the selected irregular building is more stable by providing the location of shear walls in the symmetric side.

(2) Story drift is increased as height of building increased and reduced at top floor so that shear wall frame interaction systems are very effective in resisting lateral forces induced by earthquake.

(3) The selection of especially the location and amount of shear walls is of the highest importance in strengthening. Strengthening shear wall may vary in various positions according to their positions in the plan.

From the above study can conclude that model (4) shows better performance among the other models.

\section{ACKNOWLEDGEMENT}

The author wishes to extend grateful thanks to her supervisor, Dr. San Yu Khaing, Associate Professor, Department of Civil Engineering, Mandalay Technological University, for her supervision, critical reading of manuscript, and tolerance helped in all the time of this research work. The author specially thanks to all her teachers from Department of Civil Engineering, Mandalay Technological University and her family for their supports and encouragement and also thanks to all her friends.

\section{REFERENCES}

[10Nyi] Nyi Hla Nge, U.: Reinforced Concrete Design, $1^{\text {st }}$ Ed., Pioneer Group, Yangon, (2010).

[01Lin] Lindeburg, M. R, and Baradar, M.: Seismic Design of Building Structures: AProfessional's Introduction to Earthquake Forces and Design Details, $8^{\text {th }}$ Ed.,

[02Ano] Anonymous: Building Code Requirements for Professional Publications, Inc, (2001) Structural Concrete (ACI 318-02) and Commentary (ACI 318R-02), USA: American Concrete Institute (2002).

[97Nil] Nilson, A. H.: Design of Concrete Structure, $12^{\text {th }}$ Ed., McGraw-Hill, Inc.(1997).

[97UBC] Uniform Building Code.: Structural Engineering Design Provisions, Volume $2,8^{\text {th }}$ International Conference of Building Officials, (1997).

[91Smi] Smith, B. S, and Coull, A.: "Tall Building Structure: Analysis And Design", John Wiley and Sons, Inc (1991). 